\title{
9 With open doors and windows
}

\section{Doing theology in the spirit of William James}

\author{
Jonathan Weidenbaum
}

\section{Introduction: concrete experience}

In a last essay published just before his death, William James concedes that the early work of Benjamin Paul Blood, a self-styled philosopher and fellow experimenter in nitrous oxide, manages to "charm the monist in me unreservedly" (James 1978). Despite this brief confession of sympathy for a picture of the universe as constituting a single unity, the article is largely a celebration of an eccentric and unsung thinker's turn away from monism and a confirmation, by way of direct religious experience, of James's own metaphysical pluralism.

Titled “A Pluralistic Mystic," James's final essay encapsulates much of the distinctive spirit of his approach toward different philosophical and theological frameworks. This includes, first, a search after rich and pronounced experiences wherever and whenever they may be found. Intuitions that are pathological, paranormal, and even drug-induced join religious experiences in possessing revelatory value for James and are presented as disclosing truths otherwise obscured from our more routine and ordinary forms of being. While never eschewing the importance of rational reflection upon our first-hand perceptions, a receptivity toward the freshness and immediacy of concrete experience is front and central for James. "Philosophy, like life," he affirms in Some Problems of Philosophy, "must keep the doors and windows open" (James 1996b, Ch. 4). Indeed, the analogy of open doors and windows as our proper orientation toward the world is found in numerous places throughout James's authorship. ${ }^{1}$

Second, James's exhibition of Blood demonstrates his almost uncanny ability to grasp the vital core of any religious or philosophical point of view and from what always seems like an insider's perspective. Continually arguing that beneath even the most rarefied theoretical constructs is a preconceptual feel for the way things are, James's capacity for entering into and articulating the living kernel beneath different worldviews is very likely connected with the beauty of his prose. It is one reason why a careful analysis of lived human experience is such a central preoccupation of his. 
Third, James is a seminal contributor to the philosophy of religion, one whose ruminations are often focused on the justification of the spiritual life. "I feel now," James writes triumphantly in his article on Blood, "as if my own pluralism were not without the kind of support which mystical corroboration may confer" (James 1978). Whether championing the right to believe ahead of all evidence or assessing the extent to which mystical experience may validate our philosophical convictions, the thought of James possesses endless resources for assessing theological positions in the face of what is arguably the single, most far-reaching development of the modern world: namely the ascendancy of the empirical attitude and the natural sciences.

But James's essay on Blood reveals one more tendency of his orientation toward different philosophies and religions. Even while keeping his doors and windows wide open to the full spectrum of human experience, James was never shy of making evaluative judgements with regard to different visions of the real. With regard to the contest between accepting a universe in which salvation is assured for all and one in which it isn't, James asks: "Is all 'yes, yes' in the universe?" Doesn't the fact of 'no' stand at the very core of life?" (James 1975a, 141). No matter how much his inner monist may reverberate when reading the earlier writing of Blood, a support for a more baroque and pluralistic cosmos over the pristine One of the idealists so predominate in his time remains an implacable theme of James's philosophical work. "A Pluralistic Mystic" is his last affirmation of such a commitment.

James's thoughts on religion are sufficiently abundant to allow for multiple voyages beyond the barriers of denomination. What follows is merely one creative attempt to articulate the relevance of his thought for just such an adventure. Our main strategy is to press a few of James's most essential themes into a two-storied methodology. While our first step argues for the necessity of opening our windows and doors as broadly as possible to the depth of experiences that animate different theological sensibilities, the second digs further into the thought of James in order to ascertain one of the standards we may use to evaluate between religious philosophies. Both sections begin with episodes weaned from my involvement with Theology Without Walls, debates in which Jamesean themes have proven their relevance.

Because Theology Without Walls is in its infancy, it is the perspective of the author that a concentration on methodology is more essential at this early stage than any finished or even tentative theological picture. And yet James's theological positions - his "over-beliefs" as he calls them in the Varieties - are not without their place. ${ }^{2}$ A penultimate section therefore introduces us to James's mature theological statement - mainly as a demonstration of our methodological principles at work. Our brief conclusion will ride the spirit of James beyond the assumptions underlying his method and will point the way toward a few topics well worth exploring in the future of a Theology Without Walls. 


\section{Varieties}

In more than one discussion with my colleagues in Theology Without Walls I have met with disapproval for speaking against philosophies in which the summum bonum of the spiritual life is the understanding of all things, sentient beings and galaxies alike, as manifestations of a single and perfect divine ground. One well-known philosophy of religion that sees this realization as the common goal of every authentic spiritual tradition - despite the outer doctrinal and ritual differences between faith communities - is the "perennial philosophy." Popularized by Aldous Huxley in The Perennial Philosophy, and defended by a number of authors known as the Traditionalists, the identification of our deepest selves with a formless and all-inclusive ultimate reality is here deemed as a higher plane of awareness than that of a relationship to a transcendent and personal deity. As this unitary insight is often provided by the contemplative and meditative traditions of the world East and West, monistic systems of thought like Advaita Vedanta and NeoPlatonist mystics like Meister Eckhart are therefore favorites among perennialist writers.

Skimming through portions of the chapter of mysticism in The Varieties of Religious Experience, proponents of such a perennialist-type theology would find much to delight in James's well-known study of the topic. Among the defining feature of mystical experiences for James are their seemingly noetic, or knowledge-bearing, quality, for they are felt "as states of insight into depths of truth unplumbed by the discursive intellect" (James 2004, 329). In one section, James quotes and refers to a myriad of contemplative authors - Eckhart, Silesius, Boehme, the Upanishads, and many others - and declares that the "overcoming of all the usual barriers between the individual and the Absolute is the great mystic achievement" (James 2004, 362).

But even here, within James's survey of mysticism, we are made aware of the radically different theological perspectives surrounding mystical experience. The precise reason why mystical experiences are not binding upon those who haven't undergone them is the sheer range of their interpretation: "It is dualistic in Sankhya, and monistic in Vedanta philosophy. I called it pantheistic; but the great Spanish mystics are anything but pantheists" (James 2004, 368). And stepping back to view The Varieties of Religious Experience as a whole, we see how it truly earns the beginning of its title as a varieties. For in it we are treated to testimonies ranging from those of grounded inner peace to moments of near-hallucinatory horror; from the spiritually inspired overcoming of addiction to God-intoxicated flights of ecstasy; from the confident joy and optimism of the "healthy-minded" for whom dwelling on evil is but a vice, to a concentration on the problems of existence which is the "sick soul." One of James's lengthiest descriptions is his account of the sudden reconfiguring of the self after its own inner tensions and divisions have brought it to its lowest point (James 2004, lectures 
VIII-IX). Although James later asserts that "the faith-state and mystic state are practically convertible terms," this is a religious experience more akin to what is found at a Protestant tent revival than the full self-transcendence of a Sufi dervish or contemplative, a sensibility articulated theologically by Luther, Kierkegaard, and the Neo-Orthodox theologians of the twentieth century (James 2004, 367). ${ }^{3}$

Doing Theology Without Walls in the spirit of James means being receptive to religious experiences of all kinds. It also means perceiving the meaning within all forms of experience, even those not explicitly religious. In "On a Certain Blindness in Human Beings," James writes of the manner in which our encounters with people unlike ourselves may serve as a kind of epiphany, as not only a necessary shattering of our prejudices and assumptions but also as a complete re-centering of our inner lives. ${ }^{4}$ We let our guard down before the other, and "then the whole scheme of our customary values gets confounded, then our self is riven and its narrow interests fly to pieces, then a new centre and a new perspective must be found." This is an insight akin to the I-Thou relationships of Martin Buber or our heeding of the face of our neighbor as described by Emmanuel Levinas - philosophies focused not a mystical descent within our consciousness at all, but in our active and moral comportment towards others. ${ }^{5}$

Finding nondual spiritual experiences within and across different traditions, the adherents of perennialist-type theologies interpret such experiences as more fundamental than other forms of intuition, religious and otherwise. But this comes with the cost of either ignoring or trivializing equally transformative experiences, including those which speak of an unbridgeable distance felt between the self and the other and I and a Thou. For the Jamesean involved in Theology Without Walls, a compelling reason must be found to justify prioritizing one form of intuition over another. Moreover, because nondual religious philosophies tend to lean toward a monism or quasi-pantheism in which the divine is understood as the sole or most basic reality, negative and tragic sorts of experiences are often deemed by them as either derivative or illusory. There are philosophical problems with this kind of denial, but this is a theme to which we must return later.

\section{Moral strenuousness}

Keeping our doors and windows open does not guarantee that every idea is of equal value in navigating what drafts may come through. This point is not always well taken. I recall a meeting of Theology Without Walls in which the very idea of using principles to discern the worth of different theological positions was seen as arrogant and arbitrary - the imposition of our inherited prejudices and assumptions. Isn't this a betrayal of the very purpose of a Theology Without Walls, it was asked. For isn't the practice of discriminating between theological visions just a placing up of more walls? To which one may respond that employing some kind of principle of evaluation 
is implied by the very title of a Theology Without Walls: namely, to not have walls. We do not, for instance, ignore a religious tradition because it rejects theism (i.e., Jainism and Buddhism).

But the other side of the argument is not without a few important concerns. We certainly must not shun thinkers or insights, for instance, that do not fit our a priori religious convictions. In a private letter to his fellow perennialist Huston Smith, Frithjof Schuon lambasts the thought of Kierkegaard for, among other things, its nonconformity to several of the more official and acceptable metaphysical systems as seen from a Traditionalist perspective. The religious thinker who pitted the risk-filled commitments of faith against the abstract certainties of reason and flouted the theological orthodoxies of his time must, in Schuon's recommendation, "be rejected without pity, I will even say: with horror" (Schuon 1975). No attitude can be more anathema to those who heed James's contention that in demanding conformity between different religious figures and directions of the spirit, "the total human consciousness of the divine would suffer" (James 2004, 420).

To explore theological perspectives in the spirit of William James is to employ principles of evaluation that are neither arbitrary nor smuggled in by way of our prior theological commitments. Early on in the Varieties James argues that the veridicality, or truth-bearing status, of a religious experience must be judged using the same standards as any form of experience: the sheer force by which it grips us, how well it fits in with our other beliefs, and finally its influence upon our ethical life (James 2004, 28). ${ }^{6}$ It is the last of these criteria that take us to the very heart of James's philosophical anthropology - his take on human nature.

In an early and key essay, James offers a description of rationality as the felt transition from a state of puzzle and unrest to one of contentment, ease, and sense of normal mental functioning. Philosophies that help to bring about this feeling of rationality must meet a number of conditions, one of which is to not disappoint or fail to engage our "active propensities," or "to give them no object whatsoever to press against" (James 2004, 82). Time and again in his writings, James argues in favor of those worldviews that speak not only to our spiritual intuitions but also our practical and ethical ones - those that draw upon the morally "strenuous mood" (James 2004, 211). The yearning for the unique satisfactions and rigors of the ethical life are, for James, built into our very makeup as human beings.

In another of his early essays, our cognitive and intellectual faculty is depicted as a kind of second department - one which, following our immediate sensory experience, exists primarily for the purpose of guiding our behaviors (James 2004, 113-114). For James, we are not minds in isolation, subjects cleaved off from a separate realm of objects, but whole and embodied organisms existing in and through an environment. Judging between worldviews with a concern for how they link with a few of "our deepest desires and most cherished powers," the moral life chief among them, is 
therefore no arbitrary move for James but follows from his observations as a pragmatist and consummate phenomenologist (James 2004, 82).

In his letter to Smith, Schuon complains that Kierkegaard has no conception of the intellect - what for the Traditionalists is not our faculty for discursive reasoning but our organ of direct illumination from the divine, even a spark of the Absolute within (Schuon 1975). To do theology in the spirit of William James is to be receptive to this feature common to many of the most refined spiritual philosophies, as James has done in his chapter on mysticism in The Varieties. But it is not to remain there, for we are practical and moral creatures as well as contemplative ones. Returning to his triadic picture of the human being, James diagnoses the gnostical urge to realize the completeness of our identity with the divine as an illegitimate swallowing up of our active and practical nature into our contemplative one, a disappearance of the third department of our being into the second (James 1956, 138-140). It is for these reasons that James writes sympathetically of the ascetic tendencies of the saint in the Varieties, what for him is only a more extreme representation of those for whom "passive happiness is slack and insipid, and soon grows mawkish and intolerable" (James 2004, 263).

In short, one standard employed by a Jamesean in order to discern between theological positions - a principle found directly within our experience rather than invoked arbitrarily - is to favor those perspectives that cultivate the morally strenuous life in addition to our yearning for communion with an ultimate reality.

\section{A finite god}

To summarize a Jamesean approach toward a Theology Without Walls, we should, first, be open not only to the deeper intuitions which fuel and motivate other theological positions but equally to experiences of all kinds - even those that don't sit so easily within our prior and cherished philosophical and religious assumptions. And second, we have the right to accede value to those theological positions that draw upon, and enhance, our moral energies over those that do not.

For the project of a Theology Without Walls, James's own theological conclusions are of ancillary importance to his methods. And yet James's mature speculations are a good demonstration of these principles at work.

To do philosophy and theology in the spirit of James means to acknowledge what so many monistic- and pantheistic-type perspectives so often trivialize or even deny: the unrefined edges of life, the phenomena of pain and suffering, the gaping holes which beset the universe. It is in the interest of being inclusive that in the Varieties James prefers the more complex universe of the sick soul rather than the simpler and happier metaphysics of the healthy minded. As "a rectilinear or one-storied affair," what the latter ignores "may after all be the best key to life's significance, and possibly the only openers of our eyes to the deepest levels of truth" (James 2004, 
$148,151)$. Moreover, and as we saw in the previous section, philosophies which claim that all is undergirded by a transcendental perfection too easily allow our propensities for worldly activity to atrophy, and are therefore inadequate. James's approach toward assessing different theologies leans toward the recognition of a partly precarious cosmos, a melioristic universe, as James labels it in Pragmatism, in which our efforts may play a role (James 1975b, lecture VIII).

We should recognize even how self-defeating the denial or trivializing of evil is when analyzed more carefully. For as James points out toward the end of his first lecture in A Pluralistic Universe (what is partly an expansion of his over-beliefs in the Varieties), to push for an acosmistic universe in which all pain and finitude are understood as a kind of primal ignorance, a veil blocking us from a nondual state of awareness or ultimate reality, is only to land ourselves within yet another duality. This is between the perspective of the Absolute in which all such limitations are overcome and the grittier vantage point of our own existence - one seemingly hemmed in by limitations of all kinds. In this way, to envision a perfect and all-inclusive ultimate reality would be every bit as alienating as looking upward from our lowly plane toward an all-powerful creator deity (James 1996a, 38-40). This theological picture is not only an insult to the human condition, but it deflates all motivation to rely upon our own efforts to help make the cosmos a better place.

For these reasons, the god defended by James is finite, a being limited "in power or in knowledge, or in both at once" (James 1996a, conclusions or lecture VIII). This notion of a finite deity, a god for whom we are partners with the gradual perfecting of the world rather than as passive subjects, can appeal to the ethicist in us. ${ }^{7}$ And yet because his deity is also a greater consciousness in which our smaller selves are a part, this model can appeal somewhat to the mystic's sense of union with a greater and more expansive divine reality. ${ }^{8}$

\section{Conclusion: many doors and windows}

Throughout the preceding pages we have unpacked the relevance of William James for the project of a Theology Without Walls. In no small part, this is the method of including as much of the full range of human experience, particularly religious experience, as we can. Even the standard of promoting the morally strenuous life is a principle found within our living engagement with things and is not imposed from without. Or so I have argued.

Since James's time, however, there has been some fruitful reflection on the nature and character of religious experiences. Although James's Protestant upbringing and influence may have helped bias his investigations toward the experiences of gifted individuals and against the role and mediation of institutions, the social nature of the spiritual life should never be left out of our focus. We may not go as far as James's colleague and sparring partner, 
Josiah Royce, that authentic religious experience, at least for Christianity, must be social (Royce 2001, 40-41). But social it may be. Charles Taylor offers an example of how his exultation at watching the victory of his hockey team is heightened by the fact that he rejoices with an entire city (Taylor 2003, 28). There are also some who argue for the necessity of recognizing how background beliefs and inherited dogmas infiltrate even the most ecstatic and rarefied of our experiences. Hence, it may not be just the interpretation or felt intensity of our intuitions that are shaped through culture and historical context, but their very content. ${ }^{9}$

A Jamesean approach to a Theology Without Walls is always ready to draw upon the unique experiential insights of individuals as they have surfaced in different places and times - whether such heights of awareness are achieved through meditation, discovered in the throngs of a personal crisis, or even induced through chemicals. But a contemporary Jamesean methodology must equally be attentive to experiences forged through entire communities, as well as the shared social and theological tenets in which the most defining of our spiritual intuitions have been fermented and cultivated. This may be a bit of a departure from James's own preoccupations, particularly in the Varieties. And yet peering out upon the world's divergent theological visions, it is keeping well within his spirit to open as many of our doors and windows as possible.

\section{Notes}

1 Richard Gale provides a list of James's references to open windows and doors in the introduction to The Divided Self of William James (Gale 1999, 4).

2 See the conclusion for his discussion on over-beliefs.

3 D.S. Browning affirms that "the Niebuhrs, Tillichs, and Bultmanns of the neoorthodox period could have turned to James as easily as to Kierkegaard or Heidegger" (Browning 1980).

4 Found in Talks to Teachers (James 1962).

5 For Buber's (1970) and Levinas's (1969) most definite and well-known statements on our relationships to others, see I and Thou and Totality and Infinity (Buber 1970), respectively.

6 After refuting the idea that religious experiences can be dismissed as mere products of physical disorder, what he labels "medical materialism," James suggests that "Immediate luminousness, in short, philosophical reasonableness, and moral helpfulness are the only available criteria."

7 Some may appreciate the similarity of this idea with several notions found in Lurianic Kabbalah, including the mission of human beings to enact tikkun olam, or the reparation of the cosmos. See the seventh lecture in Gershom Scholem's Major Trends in Jewish Mysticism, the landmark introduction to this topic.

8 Whether or not James has completely resolved all of the tensions between the ethical and the mystical facets within his own work, let alone for theology in general, is too large a topic for this chapter. See Gale (1999) and Weidenbaum (2013).

9 The idea that our background beliefs at least partly constitute our experiences is called constructivism. One scholar who draws our attention to James's overlooking of the manner in which historical context may inform religious experience is Proudfoot (2004). 


\section{References}

Browning, Don S. 1980. Pluralism and Personality: William James and Some Contemporary Cultures of Psychology. Lewisburg: Bucknell University Press.

Buber, Martin. 1970. I and Thou, trans. Walter Kaufmann. New York: Simon \& Schuster.

Gale, Richard. 1999. The Divided Self of William James. Cambridge: Cambridge University Press.

James, William. 1956. The Will to Believe and Other Essays in Popular Philosophy. New York: Dover.

James, William. 1962. Talks to Teachers on Psychology; and to Students on Some of Life's Ideals. Mineola: Dover Publications, Inc.

James, William, ed. 1975a. "Pragmatism." In Pragmatism and the Meaning of Truth. Cambridge: Harvard University Press.

James, William. 1978. “A Pluralistic Mystic.” In Essays in Philosophy, edited by Frederick Burkhardt, Fredson Bowers, and Ignas K. Skrupskelis. Cambridge: Harvard University Press.

James, William. 1996a. A Pluralistic Universe. Lincoln: University of Nebraska Press.

James, William. 1996b. Some Problems of Philosophy. Lincoln: University of Nebraska Press.

James, William. 2004. The Varieties of Religious Experience. New York: Sterling Publishing.

Levinas, Emmanuel. 1969. Totality and Infinity: An Essay on Exteriority, trans. Alphonso Lingis. Pittsburgh: Duquesne University Press.

Proudfoot, Wayne. 2004. "Introduction" to the Varieties of Religious Experience. New York: Sterling Publishing.

Royce, Josiah. 2001. The Problem of Christianity. Washington, DC: The Catholic University of America Press.

Scholem, Gershom. 1946. Major Trends in Jewish Mysticism. New York: Schocken Books.

Schuon, Frithjof. 1975. "Letter on Existentialism.” www.studiesincomparativereligion. com/public/articles/Letter_on_Existentialism-by_Frithjof_Schuon.aspx (accessed November 12, 2018).

Taylor, Charles. 2003. Varieties of Religion Today: William James Revisited. Cambridge: Harvard University Press.

Weidenbaum, Jonathan. 2013. "William James's Argument for a Finite Theism.” In Models of God and Alternative Ultimate Realities, edited by Jeanine Diller and Asa Kasher, 323-331. Heidelberg: Springer. doi:10.1007/978-94-007-5219-1_27 